\title{
Distribution and Phytocoenotic Context of Kobresia simpliciuscula (Wahlenb.) Mack. in South-Eastern Carpathians
}

\author{
Mihai PUȘCAȘ \\ Alexandru Borza Botanical Garden, Babeş-Bolyai University, 400015 Cluj-Napoca, Romania; mihai.puscas@ubbcluj.ro
}

\begin{abstract}
This study proposes a critical analysis of the distribution and habitat requirements of the rare arctic-alpine plant species Kobresia simpliciuscula (Wahlenb.) Mack. in the South-Eastern Carpathians. The species was recorded in this part of Carpathians only from Romania, in Bucegi Mountains. The mention of K. simpliciuscula in Rodna Mountains (Eastern Carpathians) is considered to be erroneous. K. simpliciuscula was found in the Southern Carpathians in a different habitat type compared to the one characteristic for populations in the Arctic and the Alps. The species does not grow in the pioneer phytocoenoses of the Caricion bicoloris-atrofuscae alliance but, on the contrary, in dry calciphilous alpine vegetation included in Oxytropido-Elynion. The plant communities where $K$. simpliciuscula was found in Bucegi Mountains belong to Achilleo schurii-Dryadetum (Beldie 1967) Coldea 1984. These phytocoenoses are very similar to those described for the species in Belianske Tatra Mountains (Western Carpathians, Slovakia).
\end{abstract}

Keywords: alpine habitats, chorology, Cyperaceae, rare species, Romanian Flora

\section{Introduction}

Kobresia Willd. is a relatively small genus of Cyperaceae family, one of the largest and cosmopolite families of flowering plants (Ford et al., 2006). This genus includes about 50 species (Starr and Ford, 2009), all of them being restricted to the Northern hemisphere. The highest Kobresia species diversity is located in Himalaya region, with only few species having a circumpolar distribution (Roalson $e t$ al., 2001).

Kobresia, together with Carex, Cymophyllus, Schoenoxiphium and Uncinia, is a member of tribe Cariceae Kunth ex Dumort., a monophyletic and morphologically well defined group of Cyperaceae (Starr et al., 2004). Of these, Kobresia and Schoenoxiphium are being distinguished from the other genera in Cariceae by the presence of open utricules, as compared to the closed perigynia found in Carex (Starr and Ford, 2009). Even though the flower structure clearly separates Kobresia within Cariceae, recent molecular phylogenetic studies have showed that this genus is in fact nested in Carex (Roalson et al., 2001; Waterway et al., 2009).

Two species of this genus are present in flora of Europe: Kobresia simpliciuscula (Wahlenb.) Mack. and Kobresia myosuroides (Vill.) Fiori (Chater, 1980). Both of them have an circum-arctic distribution, with scattered populations in several high mountains of Europe, Asia and North America (Meusel et al., 1965; Pârvu et al., 2009). These species are also occurring in the Romanian Carpathians, within few cited localities (Șerbănescu and Nyárády, 1966). The present study focuses on Kobresia simplicius- cula, one of the rarest plant species in the Carpathian Flora (Čeřovský et al., 1999; Dihoru and Negrean, 2009).

Kobresia simpliciuscula (K. caricina, K. bipartita, Carex simpliciuscula-simple bog sedge) is a typical arctic-alpine biogeographical element, found in the arctic and sub-arctic regions of Europe (including Svalbard, Eastern Greenland), Asia (tundra of Lena Delta, Chukotka) and North America (Alaska, Northern Canada)-(Bressoud, 1989; Meusel et al., 1965). South of the arctic regions it has a disjunct distribution, with populations centered in alpine areas of some high mountains as Rocky Mountains and Wallowa Mountains from North America (Decker et al., 2006) and in the mountains of Anatolia (Jiménez-Mejías and Luceño, 2011) or Central Asia (Bressoud, 1989). In Europe, the species is present in the Scandes, the Scottish Mountains, the Alps, the Carpathians and the Pyrenees (Bressoud, 1989; Meusel et al., 1965). In the arctic region, $K$. simpliciuscula grows in mesic to wet tundra, in almost exclusively open biotopes, on wet places along springs, rivulets, glacial torrents, glacier forelands, on calcareous substrates (Ball, 2002; Bressoud, 1989; Decker et al., 2006). It is considered a character species for the pioneer formations of the Caricion bicoloris-atrofuscae alliance (Aeschimann et al., 2004; Gafta et al., 2008) or, in North America, an indicator of rich or extreme rich fens (Johnson and Steingraeber, 2003). The species was also recorded in these types of habitats in the temperate mountains of Europe: the Alps (Bressoud, 1989) and the Pyrenees (Benito Alonso, 2006). In the Carpathians, the suitable ecological conditions for $K$. simpliciuscula are well documented only in Belianske Tatras (Western Carpathians, Slovakia; Petrík et al., 2005; 
30

Šibík et al., 2007). In this mountain range, the species can be found in a different habitat type than described above, characterized by dry, wind-exposed ridges and edges of the highest summits on limestone bedrock (the class Carici rupestris-Kobresietea bellardi). For the South-Eastern Carpathians (Romania) few and inconsistent data exists; $K$. simpliciuscula was reported to grow on basophilous alpine vegetation (on limestone), developed on windswept rocky ridges (Beldie, 1967) or as being character element for the alpine acidophilous grasslands (on siliceous bedrock) from Caricetalia curvulae (Popescu and Sanda, 1998). There are no published vegetation relevés from the Romanian Carpathians containing this species (Dihoru and Negrean, 2009).

The main goal of this study was to characterize the phytocoenotic context of Kobresia simpliciuscula in Romanian Carpathians, based on original field data. Additionally, a critical analysis of the data concerning its distribution in Romania was carried out.

\section{Materials and methods}

The existing herbarium material was revised and all available information from botanical literature was critically compiled in order to clarify the distribution of $K$. simpliciuscula in the South-Eastern Carpathians For this purpose, the following herbaria were consulted (acronyms according to Thiers, 2012): BUAG (University of Agronomical Sciences and Veterinary Medicine, Bucharest), BUC (D. Brandza Botanical Garden, Bucharest), BVS (Transylvania University of Brașov), CL (Babeș-Bolyai University, Cluj-Napoca), CLA (University of Agricultural Sciences and Veterinary Medicine, Cluj-Napoca),
CRAI (University of Craiova), I (Faculty of Biology, Alexandru Ioan Cuza University, Iaşi), IAGB (Botanical Garden, Alexandru Ioan Cuza University, Iaşi), IASI (University of Agricultural Sciences and Veterinary Medicine, Iași) and SIB (Natural History Museum, Sibiu). Several field surveys were made between 2009 and 2011 in localities from Bucegi Mountains (Southern Carpathians) and Rodna Mountains (Eastern Carpathians), where the species was reported. To describe the plant communities where the species is growing, phytosociological relevés were performed according to the Central European Phytosociological School (Cristea et al., 2004). Nomenclature of the species follows Flora Europaea (Tutin et al., 19641980).

\section{Results and discussion}

\section{Distribution in the Carpathians}

Western Carpathians: The presence of $K$. simpliciuscula in the Western Carpathians is well known and documented by both bibliographical and herbarium records. It occurs only in the small range of Belianske Tatras, on several localities in the eastern part of this massif (Čeřovský et al., 1999). This species was erroneously reported from the Polish Tatra Mts., environs of the Morskie Oko Lake (Mirek et al., 2002).

South-Eastern Carpathians: K. simpliciuscula populations from this part of the Carpathians (namely Romania) represent the South-Eastern edge of its European distribution (Fig. 1). The species was not recorded from the Balkans (Stevanović et al., 2009).

The first mentions of K. simpliciuscula from the Southern Carpathians date back to XIX ${ }^{\text {th }}$ century, the period of

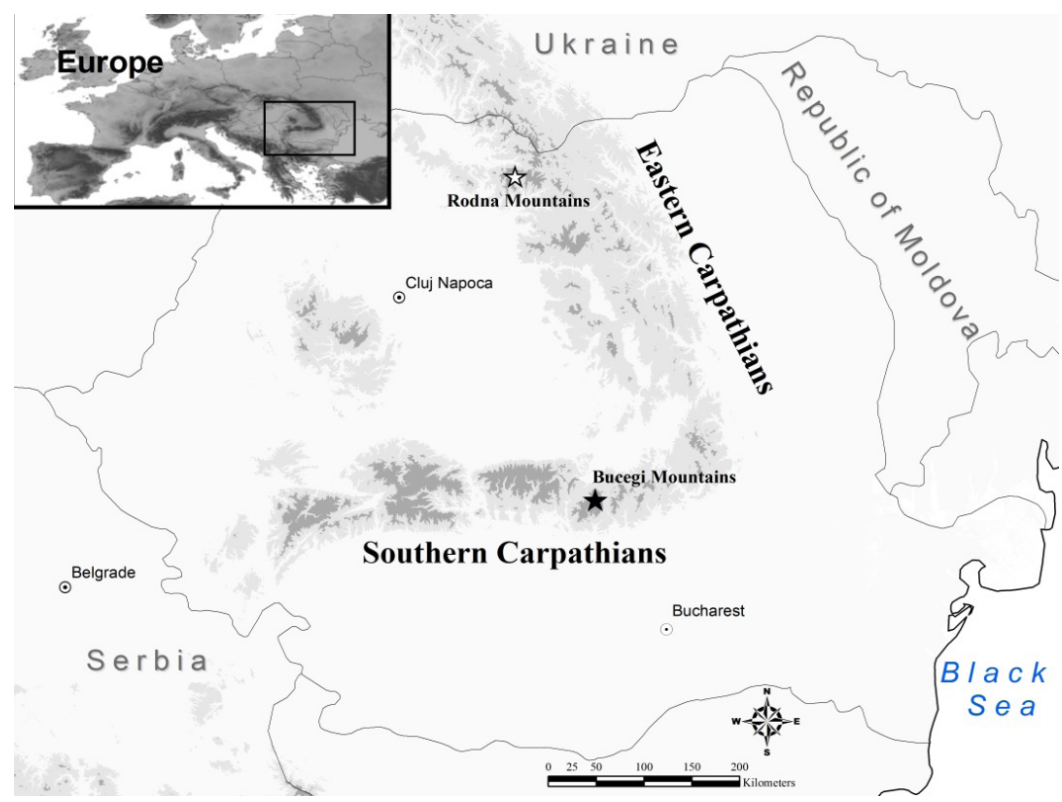

Fig. 1. Distribution of Kobresia simpliciuscula (black star) in South-Eastern Carpathians. Erroneous indications of $K$. simpliciuscula in Rodna Mountains is represented by white star. Left insert indicates the location of South-Eastern Carpathians in Europe 
the first explorations of Transylvanian flora. Schur quoted this taxon in 1866 as present in the alpine belt of Bucegi Mountains. Subsequently, the species was recorded from Romania only in this massif by Prodan $(1923,1939)$, Jávorka (1925) or Borza (1947). Beldie (1967), in his comprehensive monograph dealing with the flora and vegetation of Bucegi Mountains, offered a detailed list with all the places where $K$. simpliciuscula was indicated in this range: Baba Mare (CL), Brâna Mică (Caraiman), Valea Albă (1920 m alt.), Coștila (IAGB) on Valea Colților, Valea Mălinului (2150-2250 m alt.), Valea Seacă, Valea Urzicii and Valea Priponului (1980 m alt.), Podul Coștilelor, Colții Obârșiei (BUC, CL, BVS, I, IASI), Omu Peak, Bucşoiu (BVS, CLA), Doamnele (in the brackets there are highlighted the localities certified by herbarium material).

Stefureac reported in 1952 the second locality with $K$. simpliciuscula in Romanian Carpathians, namely on the northern slope of Pietrosul Borșei (Rodnei) Peak (Rodna Mountains, Eastern Carpathians). In that paper, the author just enumerated the species in a list of cormophytes growing as companions of the rare bryophyte Aulacomnium turgidum, without highlighting this important finding. Only in 1968 Stefureac published a new study with a detailed description of the new locality for $K$. simpliciuscula, including as well a photo with a voucher of the plants collected in 1948. The specimens in the picture had a label of BUC herbarium, but without an inventory number. Carefully examining this photo, I concluded that definitely the plants presented there have not the habitus of $K$. simpliciuscula, but, on the contrary, they show a typical morphology of Carex curvula. It especially has to be pointed out the very long and curved leaves, a character that can never be found for $K$. simpliciuscula, neither in living plants that I saw in their natural habitat in the Alps and Carpathians (Bucegi Mts.), nor verifying the specimens from Carpathians, Alps, Northern Europe or Chukotka deposited in CL Herbarium. Unfortunately, it seems that the plants collected in 1948 and published in 1968 were in fact never deposited in BUC, as the label would indicate (Petronela Comănescu, BUC curator, personal communication) or in other public herbarium. In consequence, I had no possibility to verify the vouchers. Recently, $K$. simpliciuscula was indicated by mistake from Ineu Peak in Rodna Mountains by Dihoru and Negrean (2009), but this quoted locality is in fact an erroneous citation of Ștefureac (1967).

Pietrosul Rodnei and its surroundings represent maybe the most intensively investigated region by the botanists, considering the whole range of Rodna Mountains. Starting from the XIX ${ }^{\text {th }}$ century and continuing to present, many remarkable botanical works contributed to the knowledge of the flora of this area (reviewed by Coldea $e t$ al., 1983). It seems that only Ștefureac $(1952,1968)$ listed K. simpliciuscula in Pietrosul Rodnei as being seen in the field. Afterwards, even this author was not able to find the species again in that place (Gh. Coldea, personal communication). Moreover, the habitat described by Ștefureac (1968) for K. simpliciuscula in Rodna Mts. is very different from the typical ecological preferences of the species, recorded elsewhere. K. simpliciuscula was reported in that article to be growing on acidic soil, on crystalline schists, in association with Aulacomnium turgidum (which is

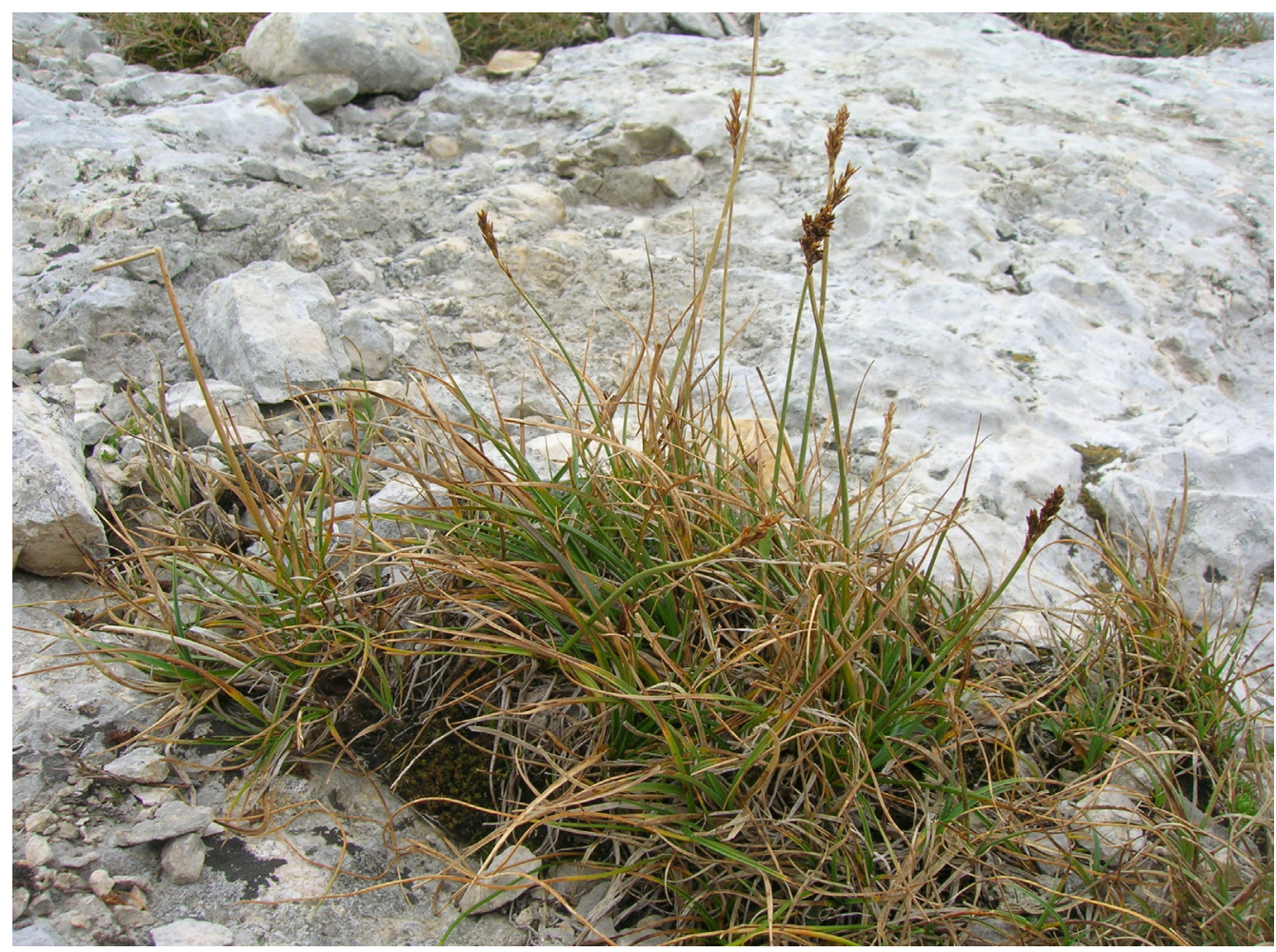

Fig. 2. Kobresia simpliciuscula in Bucegi Mountains (Baba Mare, $2261 \mathrm{msm}$ ) 
32

obligatory calcifuge, Ștefureac, 1952) and other typical acidophilous species characteristic for Caricetalia curvulae (Primula minima, Festuca airoides, Oreochloa disticha) or Salicetalia herbaceae (Salix herbacea). Notably, Carex curvula is missing from that list, even if it is the most frequent and abundant species around the summit, at that altitude (2280 msm). Besides the publication of Ștefureac (1968), $K$. simpliciuscula was characterized as calcicole in all the regions where this species was recorded: North America (Ball, 2002; Decker et al., 2006; Johnson and Steingraeber, 2003), Alps (Aeschimann et al., 2004; Konrad and Gerhart, 2000), Pyrenees (Villar et al., 2001), Western Carpathians (Čeřovský et al., 1999) and Southern Carpathians (Beldie, 1967). In addition, Bressoud (1989) emphasized that $K$. simpliciuscula is the most calcicole element among all 8 character species for Caricion bicoloris-atrofuscae. Thus, it can be concluded that the mention of $K$. simpliciuscula in Rodna Mountains is very likely to be a mistake (possible confusion with Carex curvula) and until a new, well documented record, the presence of the species in the Eastern Carpathians should be regarded as an error.

\section{Habitat description in Southern Carpathians}

K. simpliciuscula was found in Bucegi Mountains (Fig. 2) growing in very similar ecological conditions to those presented by Beldie (1967). It occupies wind-exposed rocky ridges near summits and extremely steep slopes, in the alpine belt. The species has poorly developed populations in each place that has been checked. The plants are growing on shallow soil, in the crevices of the stones. During the hot summer days the soil is often dry. From the geological point of view, the bedrock was represented only by limestone.

The phytocoenoses where K. simpliciuscula was recorded belong to Achilleo schurii-Dryadetum (Beldie 1967) Coldea 1984 (Tab. 1). The ground cover of the vegetation is moderate to low, typical for the windswept Dryas-mats in South-Eastern Carpathians. The dominant species is Dryas octopetala, seconded by Carex rupestris and Festuca versicolor. Of the diagnostic calciphilous species of the alliance Oxytropido-Elynion and higher syntaxa, several species are well represented: Kobresia myosuroides, Achillea oxyloba subsp. schurii, Minuartia sedoides and Silene acaulis. Besides K. simpliciuscula, other rare species found in the same communities are Draba kotschyi, Eritrichium nanum, Lomatogonium carinthiacum and Ranunculus alpestris.

K. simpliciuscula was found in the Southern Carpathians in a very similar habitat to the one described from Belianske Tatra Mts (Western Carpathians, Petrík et al., 2005; Šibík et al., 2007). It is certainly not a character element for the Caricetalia curvulae plant communities, as considered before in some Romanian botanical works (Popescu and Sanda, 1998). It does not grow either in moist habitats from Caricion bicoloris-atrofuscae, as in the Alps or Northern Europe. In fact, the existence of these alpine pioneer formations belonging to the alliance mentioned before was
Tab. 1. Achilleo schurii-Dryadetum (Beldie 1967) Coldea 1984 in Bucegi Mountains (Romania)

\begin{tabular}{ccc}
\hline Relevé no. & 1 & 2 \\
\hline Altitude $(\mathrm{msm})$ & 2261 & 2363 \\
\hline Surface $\left(\mathrm{m}^{2}\right)$ & 20 & 10 \\
Cover $(\%)$ & 80 & 35 \\
\hline Char. ass. & & \\
\hline Achillea oxyloba subsp. schurii & + & + \\
\hline Oxytropido-Elynion et Elinetalia & & \\
Kobresia myosuroides & +-1 & + \\
\hline Carex atrata & + & - \\
Cerastium alpinum var. lanatum & - & + \\
Minuartia sedoides & + & + \\
\hline Carici rupestris-Kobresietea & & \\
Dryas octopetala & $3-4$ & 1 \\
\hline Carex rupestris & $1-2$ & $2-3$ \\
Silene acaulis & 1 & + \\
Gentiana nivalis & + & - \\
\hline Gypsophilon
\end{tabular}

\begin{tabular}{|c|c|c|}
\hline \multicolumn{3}{|l|}{ Gypsophilion et Potentilletalia } \\
\hline Drabakotschyi & - & + \\
\hline Eritrichium nanum & - & + \\
\hline Saxifraga luteoviridis & - & + \\
\hline \multicolumn{3}{|l|}{ Seslerietalia } \\
\hline Festuca versicolor & $1-2$ & - \\
\hline Carex capillaris & 1 & - \\
\hline Carex sempervirens var. pumila & 1 & + \\
\hline Androsace chamaejasme & + & + \\
\hline Euphrasia salisburgensis & + & + \\
\hline Polygonum viviparum & + & + \\
\hline \multicolumn{3}{|l|}{ Caricetalia curvulae } \\
\hline Primula minima & + & + \\
\hline \multicolumn{3}{|l|}{ Varia } \\
\hline Kobresia simpliciuscula & +-1 & + \\
\hline Salix reticulata & 1 & - \\
\hline Armeria maritima subsp. alpina & - & + \\
\hline Lomatogonium carinthiacum & + & - \\
\hline Minuartia recurva & - & + \\
\hline Poa alpina & - & + \\
\hline Ranunculus alpestris & + & + \\
\hline Saxifraga aizoides & + & - \\
\hline Saxifraga oppositifolia & + & + \\
\hline Saxifraga paniculata & + & - \\
\hline Viola alpina & + & + \\
\hline
\end{tabular}

Place and date and of relevés: 1. Baba Mare (N: 45,413 /E: 25,467\% 27.08.2010); 2. Between Obârşia and Doamnele (N: $\left.45.434^{\circ} / \mathrm{E}: 25.453^{\circ}, 11.09 .2010\right)$

regarded as doubtful by Gafta et al. (2008). Nevertheless, more recently, based on the occurrence of several character species of Caricion bicoloris-atrofuscae in the Carpathian Flora, Schneider-Binder (2010) argued that this alpine habitat could be considered as present in Rodna Mountains and maybe in other parts of the Carpathians. It has to 
be emphasized that the presence of only one species does not necessarily indicate the presence of its characteristic habitat. The ecological behavior of range margin populations can be sometimes different comparing with the range center populations (Choler and Michalet, 2002). All these arctic-alpine species of Caricion bicoloris-atrofuscae are in Carpathians at the southern periphery of their distribution. Supplementary field data is required to confirm or infirm the existence of Caricion bicoloris-atrofuscae alliance in South-Eastern Carpathians.

\section{Conclusions}

Kobresia simpliciuscula is a typical arctic-alpine species, that has in the Romanian Carpathians the most SouthEastern populations of its entire European distribution range. This study showed that the occurrence of K. simpliciuscula in South-Eastern Carpathians is restricted to Bucegi Mountains, where it grows in dry alpine vegetation, on limestone bedrock. In older botanical literature, it was erroneously indicated from Rodna Mountains (Eastern Carpathians). Due to the very low number of localities where the species was certainly recorded, the reduced size of the populations and the restricted range of suitable alpine habitat, this species should be treated as vulnerable (VU) in Romania, following the IUCN criteria (Coldea et al., 2009).

\section{Acknowledgements}

This study was founded by Romanian Ministry of Education, Research and Innovation (CNCSIS-UEFISCSU, project PNII-Resurse Umane, PD_405/2010).

\section{References}

Aeschimann D, Lauber K, Moser DM, Theurillat J-P (2004). Flora Alpina. Belin, Paris.

Ball PW (2002). Kobresia Willdenow, 252-253 p. In: Flora of North America Editorial Committee (Ed.). Flora of North America, North of Mexico, vol. 23. Oxford University Press, Oxford.

Beldie A (1967). Flora and Vegetation of Bucegi Mountains. Editura Academiei Republicii Socialiste România, București (in Romanian).

Benito Alonso JL (2006). Vegetation of Ordesa National Park and Monte Perdido (Sobrarbe, Central Pyrenees, Aragon). Consejo de Protección de la Naturaleza de Aragón, Zaragoza (in Spanish).

Borza A (1947). Conspectus Florae Romaniae Regionumque Affinium. Cartea Românească, Cluj.

Bressoud B (1989). Contribution to the knowledge of Caricion atrofusco-saxatilis in the Alps. Phytocoenologia 17:145-270 (in French).

Čeřovský J, Feráková V, Holub J, Maglocký Š, Procházka F (1999). Červená kniha ohrožených a vzácných druhov rostlin a živočichov SR a ČR. Vol. 5. Vyšší rostliny (Slovak and Czech Red data book, vol. 5: Vascular plants). Príroda, Bratislava.

Chater AO (1980). Kobresia Willd, 289-290 p. In: Tutin TG, Heywood VH, Burges NA, Moore DM, Valentine DH, Walters SM, Webb DA (Eds.). Flora Europaea. Cambridge University Press, Cambridge.

Choler P, Michalet R (2002). Niche differentiation and distribution of Carex curvula along a bioclimatic gradient in the southwestern Alps. J Veg Sci 13:851-858.

Coldea G, Taüber F, Pînzaru G (1983). Botanical importance of Pietrosul Rodnei Nature Reserve, 160-174 p. In: Pascu Ș, Negruțiu E, Boșcaiu N, Nădișan I (Eds.). Pietrosul Rodnei Nature Reserve at 50 years since establishment. Academia Republicii Socialiste România, Cluj-Napoca (in Romanian).

Coldea G, Stoica IA, Puşcaş M, Ursu T, Oprea A (2009). Alpinesubalpine species richness of the Romanian Carpathians and the current conservation status of rare species. Biodivers Conserv 18:1441-1458.

Cristea V, Gafta D, Pedrotti F (2004). Phytosociology. Presa Universitară Clujeană, Cluj-Napoca (in Romanian).

Decker K, Culver DR, Anderson DG (2006). Kobresia simpliciuscula (Wahlenberg) Mackenzie (simple Bog Sedge): A Technical Conservation Assessment. Colorado State University, Fort Collins.

Dihoru G, Negrean G (2009). Red Book of Vascular Plants of Romania. Editura Academiei Române, București (in Romanian).

Ford BA, Iranpour M, Naczi RFC, Starr JR, Jerome CA (2006). Phylogeny of Carex subg. Vignea (Cyperaceae) based on noncoding nrDNA sequence data. Syst Bot 31:70-82.

Gafta D, Coldea G, Niculescu M, Anastasiu P, Sârbu I, Groza $G$ (2008). Habitats with uncertain presence in Romania, 82-85 p. In: Gafta D, Mountford JO (Eds.). Interpretation Manual of Natura 2000 Habitats in Romania. Risoprint, Cluj Napoca (in Romanian).

Jávorka S (1925). Magyar Flóra (Flora Hungarica). Stúdium, Budapest.

Jiménez-Mejías P, Luceño M (2011). Cyperaceae. Euro+Med Plantbase-the information resource for Euro-Mediterranean plant diversity (http://ww2.bgbm.org/EuroPlusMed).

Johnson JB, Steingraeber DA (2003). The vegetation and ecological gradients of calcareous mires in the South Park valley, Colorado. Can J Bot 81:201-219.

Konrad L, Gerhart W (2000). Flora Helvetica. Haupt Verlag, Bern.

Meusel H, Jäger E, Weinert E (1965). Comparative Chorology of the Central European Flora, vol. 1, Maps. Gustav Fischer Verlang, Jena (in German).

MirekZ, Piękoś-Mirkowa H, Zając A, Zając M, Paul W, Ronikier M, Bernacki L, Cieślak E, Głowacki Z, Leda M, Mitka J, Paśnik A, Rostański K, Szeląg Z, Wójcicki JJ, Zalewska- 
34

Gałosz J, Zieliński J, Żukowski W (2002). Flowering plants and pteridophytes of Poland. A checklist. Biodiversity of Poland, vol. 1. W. Szafer Institute of Botany, Polish Academy of Sciences, Kraków.

Pârvu M, Pârvu AE, Crăciun C, Barbu-Tudoran L, Pușcas M (2009). Ultrastructure and development of Anthracoidea elynae ustilospores. Not Bot Horti Agrobo 37:41-44.

Petrík A, Šibík J, Valachovič M (2005). The class Carici rupestrisKobresietea bellardii Ohba 1974 also in the Western Carpathians. Hacquetia 4:33-51.

Popescu A, Sanda V (1998). Synopsis of the spontaneous cormophyte flora from Romania. Acta Horti Botanici Bucurestiensis 1-336 p. (in Romanian).

Prodan I (1923). Flora for Determination and Description of Plants Growing in Romania. Cartea Românească SA, Cluj (in Romanian).

Prodan I (1939). Flora for Determination and Description of Plants Growing in Romania, $2^{\text {nd }}$ ed. Cartea Românească, Cluj (in Romanian).

Roalson EH, Columbus JT, Friar EA (2001). Phylogenetic relationships in Cariceae (Cyperaceae) based on ITS (nrDNA) and trnT-L-F (cpDNA) region sequences: Assessment of subgeneric and sectional relationships in Carex with emphasis on section Acrocystis. Syst Bot 26:318-341.

Schneider-Binder E (2010). Alpine wet habitat types of community interest in the Rodna Mountains National Park (Eastern Carpathians, Romania). Transylv Rev System Ecol Res 9:101-112.

Schur JF (1866). Enumeratio Plantarum Transsilvaniae. Guilielmum Braumüller, Vindobonae.

Šibík J, Petrík A, Valachovič M, Dúbravcová Z (2007). Carici rupestris-Kobresietea bellardii, p 209-249. In: Kliment J, Valachovič M (eds). Plant communities of Slovakia. $4^{\text {th }}$ vol. Alpine vegetation. Veda, Bratislava (in Slovak).

Starr JR, Harris SA, Simpson DA (2004). Phylogeny of the unispicate taxa in Cyperaceae tribe Cariceae I: Generic relationships and evolutionary scenarios. Syst Bot 29:528544.
Starr JR, Ford BA (2009). Phylogeny and Evolution in Cariceae (Cyperaceae): Current Knowledge and Future Directions. Bot Rev 75:110-137.

Stevanović V, VukojičićS, Šinžar-SekulićJ, Lazarević M, Tomović G, Tan K (2009). Distribution and diversity of Arctic-Alpine species in the Balkans. Plant Syst Evol 283:219-235.

Şerbănescu I, Nyárády EI (1966). Fam. 122. Cyperaceae A.L. Juss, 613-848 p. In: Nyárády EI (Ed.). Flora of the Socialist Republic of Romania. Editura Academiei Republicii Socialiste România, București (in Romanian).

Ştefureac T (1967). The importance of nature reserves in the region of Suceava. A. Forest Reserves. Comunicări de Botanică, a va Consfătuire de Geobotanică 93-111 p. (in Romanian).

Stefureac TI (1952). The association with Aulacomnium turgidum (WhIb.) Schwegr. from Rodna Mountains. Buletin Științific Secțiunea de Științe Biologice, Agronomice, Geologice și Geografice 4:381-399 (in Romanian).

Ștefureac TI (1968). Contribution on the knowledge of the distribution of certain Angiospermae in the South-Eastern Carpathians. Rev Roum Bio, Ser Bot 13:303-312.

Thiers B (2012). Index Herbariorum: A global directory of public herbaria and associated staff. New York Botanical Garden's Virtual Herbarium: http://sweetgum.nybg.org/ ih/.

Tutin TG, Heywood VH, Burges NA, Moore DM, Valentine DH, Walters SM, Webb DA (Eds.) (1964-1980). Flora Europaea. Cambridge University Press, Cambridge.

Villar L, Sesé JA, Ferrández JV (2001). Atlas of the Flora of the Aragonese Pyrenees, II. Consejo de Protección de la Naturalezade Aragón, Instituto de Estudios Altoaragonenses, Huesca (in Spanish).

Waterway MJ, Hoshino T, Masaki T (2009). Phylogeny, species richness, and ecological specialization in Cyperaceae tribe Cariceae. Bot Rev 75:138-159. 